\title{
THROUGH THE LOOKING-GLASS: EXPLORING THE WONDERLAND OF “OTHER” FEMALE PORTRAYALS IN ADVERTISING
}

Dr Tania Maree

Department of Marketing Management University of Pretoria

Private bag X20, Hatfield, Pretoria, 0028, Republic of South Africa

Tel: +27 12420 3418; Fax: +27123625085

E-mail: Tania.Maree@up.ac.za

\begin{abstract}
Research on gender portrayals in advertising are prolific and mostly focus on stereotypical roles. However, there is no previous research report analysing portrayals that fall into the "other" category of female roles. This paper aims to provide an outline of female role portrayals in advertising and, importantly, to examine the "other" role category for new portrayals. A quantitative content analysis was conducted on samples of South African magazine and television advertisements. The findings indicate that the stereotypical decorative role was prevalent in magazine advertisements. In television advertisements the product user was the person most often featured. A detailed analysis of the "other" category in both media revealed four new role portrayals. These new roles represent a different view of the modern woman and may be used to differentiate effectively those brands in media that are cluttered with advertising messages. The research provides direction for future content analytic studies on the topic of female portrayals in advertising.
\end{abstract}

Keywords advertising, magazines, television, female portrayals, new roles, stereotypes, South Africa

\section{INTRODUCTION}

A voluptuous vixen is draped seductively over a sports car; on the next page a homely mommy is feeding children breakfast cereal. Advertising is often criticised - by society and scholars - for portraying women in stereotypical, limiting roles. That women are portrayed 
in stereotypical roles has been shown in research dating back as far as 1971 (Courtney and Lockeretz 1971, 95). This practice continues in the new millennium, as confirmed by a review of 30 studies since 2000 (Furnham and Paltzer 2010). Research on gender stereotyping in advertising is abundant, however very little attention is given to different or new portrayals that emerge from advertising in popular (and thus widely exposed) media.

Many previous studies identify stereotypical roles and include a category for "other" (roles that are not typical). However, an extensive search of published articles on the topic found no reported in-depth analysis of this category. This represents a clear gap in the literature on the topic. Such analysis could conceivably reveal different or new portrayals.

The purpose of this paper is, firstly, to examine the roles in which women are usually portrayed and, secondly, to determine if women are portrayed in any new roles. This research builds on gender role categories developed by McArthur and Resko (1975) and subsequent studies, including review works by Furnham and Mak (1999), Eisend (2010) and Furnham and Paltzer (2010). The latter lament the lack of a sound theoretical framework suitable to gender role research (Furnham and Paltzer 2010, 223). Using South African samples of magazine and television advertisements from the most popular vehicles in each medium, a quantitative content analysis was conducted. A coding scheme based on gender roles identified in literature was developed; care was given to incorporate specifically the limited previous research on female portrayals in South Africa. Then, using an inductive qualitative coding process, further in-depth analysis of the "other" category was conducted in order to identify and define new role portrayals.

The analysis of the "other" category revealed four new roles that do not appear in previous research. These different depictions may reflect new thinking - a movement away from stereotypical imagery. Featuring atypical portrayals in advertising may allow brands to differentiate themselves from their competitors. When considering the high levels of advertising clutter (competing messages) in mass media advertising, differentiation is crucial. The study also contributes towards developing a theoretical framework for content analysis studies focusing on female portrayals, as it provides clear category definitions. 
The paper provides an overview of gender role research in advertising and a background to the study. The methodology is described and is followed by the main findings. Discussions and recommendations are provided as well as directions for future research.

\section{AN OVERVIEW OF RESEARCH ON GENDER ROLES IN ADVERTISING}

Although different methodologies are used to study gender role portrayals, Rudy, Popova and Linz $(2010,707)$ assert that content analysis is commonly utilised. Content analysis uses coding schemes to examine content. The coding categories should be defined clearly. According to Neuendorf $(2011,279)$, the lack of standardised codebooks means that content analysts rely on other research to develop coding schemes.

Content analytic research on gender roles spans a wide time frame - as far back as 1971 when Courtney and Lockeretz (1971) explored female portrayals in magazine advertisements. Four years following that, the seminal study by McArthur and Resko (1975) set the scene for research on the topic. A large number of studies in subsequent years used their scheme, some employing slightly different approaches (Collins 2011; Ferguson, Kreshel and Tinkham 1990; Sullivan and O'Connor 1988). Many studies included a category for "other"; however, none reported investigating it to reveal possible new portrayals.

Over the decades some review and/or meta-analytical studies provided overviews of research in the field. Bretl and Cantor (1988) examined trends in gender portrayals over 15 years and Furnham and Paltzer conducted two often-cited reviews in 1999 and 2010. Their 2010 review listed 15 roles that were used in coding the role variable across 30 studies in various countries (Furnham and Paltzer, 2010), including McArthur and Resko's (1975). These review studies did not elaborate on any portrayals arising from analysis of the "other" category.

Content analyses of gender role portrayals are conducted across various media and contexts. Studies have analysed mass advertising media such as magazines (Busby and Leichty 1993; Döring and Pöschl 2006), television (Bartsch, Burnett, Diller and Rankin- 
Williams 2000; Chow-Hou, Mei-Lan and Siok-Kuan 1995) and radio (Monk-Turner, Kouts, Parris and Webb 2007). The majority focused on comparing male and female portrayals (Ford, Voli, Honeycutt and Casey 1998; Furnham, Pallangyo and Gunter 2001; Luyt 2011), some examined female (Ferrante, Haynes and Kingsley 1988; Ishak 2013) or male portrayals (Kolbe and Albanese 1996; Skelly and Lundstrom 1981). Contextually, many studies focused on a specific country (Cagli and Durukan 1989; Furnham and Spencer-Bowdage 2002; Ishak 2013; Mwangi 1996), whereas others conducted cross-cultural comparisons (Gilly 1988; Paek, Nelson and Vilela 2011; Siu and Au 1997).

It is clear from the preceding that studies on gender portrayals in advertising encompass a range of developed and developing countries and media. Collectively, these studies show that advertising images are generally stereotypical. Advertising is seen as a reflection of societal norms (Holtzhausen, Jordaan and North 2011), and thus may affect perceptions of social reality. Following this logic, the expectation is that roles of women would be portrayed holistically in advertising. In contrast, many scholars agree that advertising portrayals do not adequately reflect gender roles (Gilly 1988, 84; Milner and Higgs 2004, 81; Paek et al. 2011, 204).

If this is true, a question arises: Do current advertising analyses really delve into what is portrayed? It seems that most studies use stereotypes as a basis for analysis, and do not attempt to explore portrayals that reside outside these "norms". Indeed, Furnham and Paltzer $(2010,223)$ assert that a review of 30 gender role studies indicated a lack of "...imaginative growth in the content categories...".

Table 1 presents a summary of role categories over the decades since the 1970s (focusing on portrayals of adults). 
Table 1 Summary of gender role categories in previous research ${ }^{i}$

\begin{tabular}{|c|c|c|c|c|}
\hline \multirow[t]{2}{*}{ Role categories } & \multicolumn{4}{|l|}{ Sources } \\
\hline & 1970s & $1980 \mathrm{~s}$ & 1990s & $2000 \mathrm{~s}$ \\
\hline $\begin{array}{l}\text { Autonomous/ } \\
\text { independent/ } \\
\text { strong woman/ } \\
\text { being served / } \\
\text { neutral }\end{array}$ & & & $\begin{array}{l}\text { (Wee, Choong and } \\
\text { Tambyah 1995) }\end{array}$ & $\begin{array}{l}\text { (Furnham and Paltzer 2010; Hung and Li } \\
\text { 2006; Plakoyiannaki and Zotos 2009) }\end{array}$ \\
\hline Celebrity & $\begin{array}{l}\text { (Dominick and } \\
\text { Rauch 1972) }\end{array}$ & $\begin{array}{l}\text { (Cagli and Durukan } \\
\text { 1989; Ferrante et al. } \\
\text { 1988; Gilly 1988) }\end{array}$ & $\begin{array}{l}\text { (Mazzella, Durkin, Cerini } \\
\text { and Buralli 1992; Siu and } \\
\text { Au 1997) }\end{array}$ & $\begin{array}{l}\text { (Das 2011; Furnham and Paltzer 2010; } \\
\text { Milner 2005) }\end{array}$ \\
\hline $\begin{array}{l}\text { Decorative/ } \\
\text { physically } \\
\text { beautiful/ flower } \\
\text { vase }\end{array}$ & & $\begin{array}{l}\text { (Cagli and Durukan } \\
\text { 1989; Sullivan and } \\
\text { O'Connor 1988) }\end{array}$ & (Ferguson et al. 1990) & $\begin{array}{l}\text { (Bolliger 2008; Döring and Pöschl 2006; } \\
\text { Furnham and Paltzer 2010; Hung and Li } \\
\text { 2006; Johnson, Rowan and Lynch 2006; } \\
\text { Nassif and Gunter 2008; Plakoyiannaki } \\
\text { and Zotos 2009; Razzouk, Seitz and } \\
\text { Vacharante 2003; Valls-Fernández and } \\
\text { Martínez-Vicente 2007) }\end{array}$ \\
\hline $\begin{array}{l}\text { Dependent/ } \\
\text { supporting/ serving }\end{array}$ & & $\begin{array}{l}\text { (Cagli and Durukan } \\
\text { 1989) }\end{array}$ & (Wee et al. 1995) & $\begin{array}{l}\text { (Döring and Pöschl 2006; Furnham and } \\
\text { Paltzer 2010; Koerning and Granitz } \\
\text { 2006; Plakoyiannaki and Zotos 2009; } \\
\text { Razzouk et al. 2003) }\end{array}$ \\
\hline $\begin{array}{l}\text { Homemaker } \\
\text { /housewife }\end{array}$ & $\begin{array}{l}\text { (McArthur and } \\
\text { Resko 1975) }\end{array}$ & $\begin{array}{l}\text { (Cagli and Durukan } \\
\text { 1989; Gilly 1988) }\end{array}$ & $\begin{array}{l}\text { (Mazzella et al. 1992; } \\
\text { Rudansky-Kloppers 1991; } \\
\text { Siu and Au 1997) }\end{array}$ & $\begin{array}{l}\text { (Bolliger 2008; Collins 2011; Das 2011; } \\
\text { Furnham and Paltzer 2010; Koerning } \\
\text { and Granitz 2006; Milner 2005; } \\
\text { Plakoyiannaki and Zotos 2009; Razzouk } \\
\text { et al. 2003) }\end{array}$ \\
\hline $\begin{array}{l}\text { Interviewer/narrato } \\
\text { r/presenter/ voice } \\
\text { of authority } \\
\text { (expert) }\end{array}$ & $\begin{array}{l}\text { (McArthur and } \\
\text { Resko 1975) }\end{array}$ & $\begin{array}{l}\text { (Cagli and Durukan } \\
\text { 1989; Gilly 1988) }\end{array}$ & $\begin{array}{l}\text { (Mazzella et al. 1992; Siu } \\
\text { and Au 1997) }\end{array}$ & $\begin{array}{l}\text { (Das 2011; Furnham and Paltzer 2010; } \\
\text { Milner 2005; Plakoyiannaki and Zotos } \\
\text { 2009) }\end{array}$ \\
\hline $\begin{array}{l}\text { Mannequin (model } \\
\text { of clothing) }\end{array}$ & $\begin{array}{l}\text { (Dominick and } \\
\text { Rauch 1972) }\end{array}$ & $\begin{array}{l}\text { (Ferrante et al. } \\
\text { 1988) }\end{array}$ & (Rudansky-Kloppers 1991) & (Razzouk et al. 2003) \\
\hline Parent & $\begin{array}{l}\text { (McArthur and } \\
\text { Resko 1975) }\end{array}$ & $\begin{array}{l}\text { (Bretl and Cantor } \\
\text { 1988; Gilly 1988; } \\
\text { Sullivan and } \\
\text { O'Connor 1988) }\end{array}$ & $\begin{array}{l}\text { (Ferguson et al. 1990; } \\
\text { Mazzella et al. 1992; } \\
\text { Mwangi 1996; Rudansky- } \\
\text { Kloppers 1991; Siu and Au } \\
\text { 1997; Wee et al. 1995) }\end{array}$ & $\begin{array}{l}\text { (Bolliger 2008; Collins 2011; Das 2011; } \\
\text { Döring and Pöschl 2006; Furnham and } \\
\text { Paltzer 2010; Hung and Li 2006; } \\
\text { Ibroscheva 2007; Koerning and Granitz } \\
\text { 2006; Milner 2005; Valls-Fernández and } \\
\text { Martínez-Vicente 2007) }\end{array}$ \\
\hline Product user & & & (Furnham and Mak 1999) & $\begin{array}{l}\text { (Furnham et al. 2001; Ibroscheva 2007; } \\
\text { Johnson et al. 2006; Plakoyiannaki and } \\
\text { Zotos 2009) }\end{array}$ \\
\hline $\begin{array}{l}\text { Romantic } \\
\text { relationships } \\
\text { (spouse/girlfriend/ } \\
\text { boyfriend/ } \\
\text { date/fiancée) } \\
\end{array}$ & $\begin{array}{l}\text { (Dominick and } \\
\text { Rauch 1972; } \\
\text { McArthur and } \\
\text { Resko 1975) }\end{array}$ & $\begin{array}{l}\text { (Bretl and Cantor } \\
\text { 1988; Ferrante et al. } \\
\text { 1988; Sullivan and } \\
\text { O'Connor 1988) }\end{array}$ & $\begin{array}{l}\text { (Ferguson et al. 1990; } \\
\text { Mazzella et al. 1992; } \\
\text { Mwangi 1996; Rudansky- } \\
\text { Kloppers 1991; Siu and Au } \\
\text { 1997; Wee et al. 1995) } \\
\end{array}$ & $\begin{array}{l}\text { (Bolliger 2008; Collins 2011; Das 2011; } \\
\text { Furnham and Paltzer 2010; Koerning } \\
\text { and Granitz 2006; Milner 2005; } \\
\text { Plakoyiannaki and Zotos 2009; Razzouk } \\
\text { et al. 2003) }\end{array}$ \\
\hline $\begin{array}{l}\text { Social relationships } \\
\text { (friends/siblings } \\
\text { /familial) }\end{array}$ & & $\begin{array}{l}\text { (Cagli and Durukan } \\
\text { 1989; Sullivan and } \\
\text { O'Connor 1988) }\end{array}$ & $\begin{array}{l}\text { (Rudansky-Kloppers 1991; } \\
\text { Wee et al. 1995) }\end{array}$ & $\begin{array}{l}\text { (Das 2011; Furnham and Paltzer 2010; } \\
\text { Plakoyiannaki and Zotos 2009) }\end{array}$ \\
\hline $\begin{array}{l}\text { Sex object / urban } \\
\text { sophisticate }\end{array}$ & $\begin{array}{l}\text { (Dominick and } \\
\text { Rauch 1972) }\end{array}$ & & $\begin{array}{l}\text { (Mazzella et al. 1992; } \\
\text { Rudansky-Kloppers 1991; } \\
\text { Wee et al. 1995) }\end{array}$ & $\begin{array}{l}\text { (Bolliger 2008; Collins 2011; Döring and } \\
\text { Pöschl 2006; Furnham and Paltzer 2010; } \\
\text { Grau, Roselli and Taylor 2007; Hung and } \\
\text { Li 2006; Ibroscheva 2007; Johnson et al. } \\
\text { 2006; Koerning and Granitz 2006; } \\
\text { Monk-Turner et al. 2007; Plakoyiannaki } \\
\text { and Zotos 2009; Razzouk et al. 2003) }\end{array}$ \\
\hline Worker (all types) & $\begin{array}{l}\text { (Dominick and } \\
\text { Rauch 1972; } \\
\text { McArthur and } \\
\text { Resko 1975) }\end{array}$ & $\begin{array}{l}\text { (Bretl and Cantor } \\
\text { 1988; Ferrante et al. } \\
\text { 1988; Gilly 1988; } \\
\text { Sullivan and } \\
\text { O'Connor 1988) }\end{array}$ & $\begin{array}{l}\text { (Mazzella et al. 1992; } \\
\text { Mwangi 1996; Rudansky- } \\
\text { Kloppers 1991; Siu and Au } \\
\text { 1997) }\end{array}$ & $\begin{array}{l}\text { (Das 2011; Furnham and Paltzer 2010; } \\
\text { Hung and Li 2006; Ibroscheva 2007; } \\
\text { Koerning and Granitz 2006; Milner } \\
\text { 2005; Nassif and Gunter 2008; } \\
\text { Plakoyiannaki and Zotos 2009; Razzouk } \\
\text { et al. 2003; Valls-Fernández and } \\
\text { Martínez-Vicente 2007) }\end{array}$ \\
\hline Other/unknown & $\begin{array}{l}\text { (McArthur and } \\
\text { Resko 1975) }\end{array}$ & $\begin{array}{l}\text { (Cagli and Durukan } \\
\text { 1989; Gilly 1988) }\end{array}$ & $\begin{array}{l}\text { (Ferguson et al. 1990; } \\
\text { Mazzella et al. 1992; Siu } \\
\text { and Au 1997; Wee et al. } \\
\text { 1995) }\end{array}$ & $\begin{array}{l}\text { (Das 2011; Furnham and Paltzer 2010; } \\
\text { Milner 2005) }\end{array}$ \\
\hline
\end{tabular}


The categories in Table 1 include those from Furnham and Paltzer's (2010) review (based on McArthur and Resko's scheme) and other studies that used different approaches. Note that in Table 1 similar (for example housewife/homemaker) categories were combined, and the varying names used by the cited authors are provided.

Eisend $(2010,437)$ asserts that content analysts do not report conceptual frameworks for role categories. The studies cited here support this as most of these do not report clear definitions. This presents a problem for replication, and content analysts therefore have to make assumptions regarding the meaning of role categories in other research. Because of this, one standardised format for analysing gender roles is not commonly used, although variations of McArthur and Resko's (1975) scheme seem to be the most widespread.

Some studies note a category of "other"; however, none reports further examination of the depictions within it. The "other" category thus represents an opportunity to analyse atypical depictions and possibly reveal new roles.

\section{RESEARCH OBJECTIVES}

The objectives of the study were firstly to identify the roles portrayed by women in advertisements, and secondly to examine the "other" portrayals in order to reveal new roles. The latter is the main focus of this paper.

\section{METHODOLOGY}

\section{Method}

Following a positivistic quantitative paradigm, a cross-sectional, descriptive study was conducted. A quantitative content analysis of advertisements featuring at least one woman was conducted using a coding scheme adapted from previous research.

Content analysis uses coding schemes (code books and coding sheets), which operationalise the investigated concepts to establish relevant, valid coding categories (White and Marsh 
2006, 31). A salient characteristic of good content analysis research is that the categories are developed carefully, unambiguously and defined clearly.

To develop the categories for this study, commonly identified roles were summarised from literature and overlapping categories combined to use in a pilot study. Considering the context of the study - a developing country (South Africa) - with its unique and diverse history, categories from previous research in South Africa were specifically included. Rudansky-Kloppers' (1991) categories included housewife, mannequin, mother/nurturer, romantic, sex object, social being and working woman. These categories differed from McArthur and Resko's (1975) in that they excluded celebrity and included the mannequin and the social being.

Following a precursory exploration of advertisements, and considering the prevalence of such roles in previous research, the decorative woman and product user were also included in the pilot study. The resultant categories included work/career woman, decorative, homemaker, mannequin, mother, product user, the romantic, sex object, social being and other. Based on the results of the pilot study, the categories were further refined for the final code book. The pilot study revealed that the "other" category was the largest, prompting a further exploration thereof. Half of these portrayals were of women that served no specific purpose - they merely served to fill a space. This was added to the final coding scheme as a "background element". A category of "other" was included to code any portrayals that did not fit into the specified categories.

Utilising a similar procedure as Rudansky-Kloppers $(1991,139)$, the role categories were defined using four criteria: character, props (supporting elements), setting and advertised product. The character's appearance, manner and actions are considered important in terms of what is communicated (Dyer 2003, 78), and are used as cues to the portrayal. Similarly, the props, setting and product indicate the meaning of the role. Thus: a woman (character) cooking (action) in a kitchen (setting) using the advertised brand of pots (product) can be classified as a homemaker. Table 2 presents a summary of the female role categories used in the final study. 
Table 2 Female role categories used in the study ${ }^{\mathrm{ii}}$

\begin{tabular}{|c|c|}
\hline Role category & Definition \\
\hline Career woman & $\begin{array}{l}\text { A typical working woman who focuses on a work-related activity. She poses } \\
\text { professionally and her attire indicates a working role. Props include items related to } \\
\text { performing a work activity and the environment is a work space. }\end{array}$ \\
\hline Homemaker & $\begin{array}{l}\text { The character is dressed informally and is performing activities related to household } \\
\text { work, using or surrounded by props that relate to household tasks in an in-home } \\
\text { setting. }\end{array}$ \\
\hline Mannequin & $\begin{array}{l}\text { The character wears or displays the product, generally fashion attire. Her expression } \\
\text { is neutral and the setting, props and other people are not focal points. The } \\
\text { portrayal's main function is to serve as a display vehicle for the product(s). }\end{array}$ \\
\hline Mother & $\begin{array}{l}\text { The woman is depicted focussing on a child/children and is performing a nurturing } \\
\text { action. The setting is informal and the props support a parenting action. }\end{array}$ \\
\hline $\begin{array}{l}\text { Physically decorative } \\
\text { woman }\end{array}$ & $\begin{array}{l}\text { The character is an example of the physical ideal and is presented as a glamorous } \\
\text { focal point. Other elements in the advertisement are secondary and serve to } \\
\text { support the decorative ideal. }\end{array}$ \\
\hline Product user & $\begin{array}{l}\text { The woman is using or preparing to use the advertised product. The props and } \\
\text { environment are related to the product and/or conducive to its use. }\end{array}$ \\
\hline Sex object & $\begin{array}{l}\text { This character is sexually alluring, dressed provocatively/scantily and her expression } \\
\text { is sexually charged. The product may be irrelevant as her main function is to attract } \\
\text { attention. }\end{array}$ \\
\hline Social being & $\begin{array}{l}\text { The woman is portrayed with other people, engaging in some social activity, which } \\
\text { is supported by the props. The setting is usually informal and relaxed and } \\
\text { interactions are socially oriented. }\end{array}$ \\
\hline The Romantic & $\begin{array}{l}\text { This character is depicted with and focused on a man. Her expression reflects a } \\
\text { positive emotion regarding the man and interaction signifies romance. This } \\
\text { portrayal includes inter alia wife/girlfriend depictions. }\end{array}$ \\
\hline Background element & $\begin{array}{l}\text { This is a non-functional portrayal that forms part of the visuals in an advertisement } \\
\text { but is not active in any way nor can be classified as any discernable role. }\end{array}$ \\
\hline Other & $\begin{array}{l}\text { Any depiction that cannot be included in any of the defined categories. (Coders were } \\
\text { required to provide a description of such portrayals to enable further analysis) }\end{array}$ \\
\hline
\end{tabular}

To ensure reliability, three independent coders coded the data and agreement scores were measured. As the role variable could have multiple responses (more than one role in the same advertisement), per cent agreement was used to determine reliability. Measures such as Krippendorff's alpha could not be used due to the variable's multiple response nature. Per cent agreement is used by many content analysts (Furnham et al. 2001; Hung and Li 2006; Ibroscheva 2007). For the magazine sample, reliability was 82 per cent, and for television 84.1 per cent - acceptable scores according to Neuendorf $(2002,143)$.

\section{Sampling}

The population for the magazine sample included all magazines published in South Africa in 2009. The South African Audience Research Foundation's (SAARF) “All Products and Media Survey" (AMPS) listings for magazine readership comprised the sample frame. Magazines with readership figures exceeding 500000 were selected as high readership is considered to 
indicate popularity and thus wide exposure. The study followed common practice by using readership figures for sampling (Ford et al. 1998, 116; Grau et al. 2007, 59; Hung and Li 2006, 15; Nam, Lee and Hwang 2011, 227; Razzouk et al. 2003, 121). The sample excluded specialist publications (for example retail magazines or television guides) as the readers of such magazines represent narrow target audiences - the purpose of the study was to examine data representing broader audiences (thus representing the "common man"). The selected magazines and readership figures are presented in Table 3.

Table 3 Readership figures of the sample of magazines

\begin{tabular}{|l|c|}
\hline Magazine & Readership (in 000s) \\
\hline Bona & 2833 \\
\hline Cosmopolitan & 984 \\
\hline Fairlady & 927 \\
\hline FHM & 713 \\
\hline O' The Oprah Magazine & 565 \\
\hline Rooi Rose & 858 \\
\hline Sarie & 788 \\
\hline True Love & 2943 \\
\hline You & 2071 \\
\hline
\end{tabular}

Source: South African Advertising Research Foundation (2009a)

Monthly and weekly issues published in March and April were selected; the first monthly issue for weeklies to ensure equal representation. Table 3 shows that the most popular magazines at the time featured predominantly female readership.

For the television sample, the population included all South African television broadcasters and the sample frame consisted of the SAARF's cumulative television channel reach (Cume Reach) figures. In 2009, South African television viewers had access to six broadcasters: SABC 1, 2 and 3, e.tv, M-Net and DStv. According to the Cume Reach figures (South African Audience Research Foundation 2009b), the most popular channels (\% of total audience) in January 2009 were the free-to-air channels: SABC 2 (98.6\%), SABC 1 (98.4\%), SABC 3 (96.8\%) and e.tv (96.3\%). The subscription channels featured figures of 48.5 per cent (DStv) and 32.9 per cent (M-Net). Based on these figures, the sample was drawn from the free-to-air channels, focusing on the prime time slot (18:00-22:00) during March (owing to practical and time constraints, one month only was used). 


\section{Sampling procedures}

Non-probability purposive sampling, which is frequently used in content analyses, was utilised. According to Neuendorf $(2002,87)$ it is useful when relevant content is difficult to find using a random sample. The objective was to analyse advertisements featuring women; probability sampling could have resulted in elements that do not fit this purpose.

\section{Sample sizes}

A total of 625 full- or double-page advertisements were found in the magazines, and 54.7 per cent ( $n=342)$ featured women. When duplicates were excluded, the sample size was 203 advertisements. A total of 3556 television advertisements were found; 39.5 per cent $(n=1404)$ featured women. Owing to the repetitive nature of television as an advertising medium, when duplicates were excluded, the sample consisted of 245 advertisements. Thus the total number of advertisements analysed was 448 .

It is important to note that duplicates were excluded according to common practice. According to Eisend (2010), only 28 per cent of the 64 studies in his meta-analysis of studies included duplicates. Previous studies do not always report whether duplicates were included and sample sizes vary greatly. Examples of sample sizes in previous research are: Ibroscheva $(2007,60)$ 127; Razzouk et al. $(2003,121)$ 100; Rudansky-Kloppers $(1991,159)$ 309; and Silverstein and Silverstein $(1974,76) 496$.

\section{FINDINGS}

Female role portrayals in magazine advertisements

Figure 1 depicts the frequencies of the roles in the magazine sample. 
Figure 1 Role portrayals in magazine advertisements

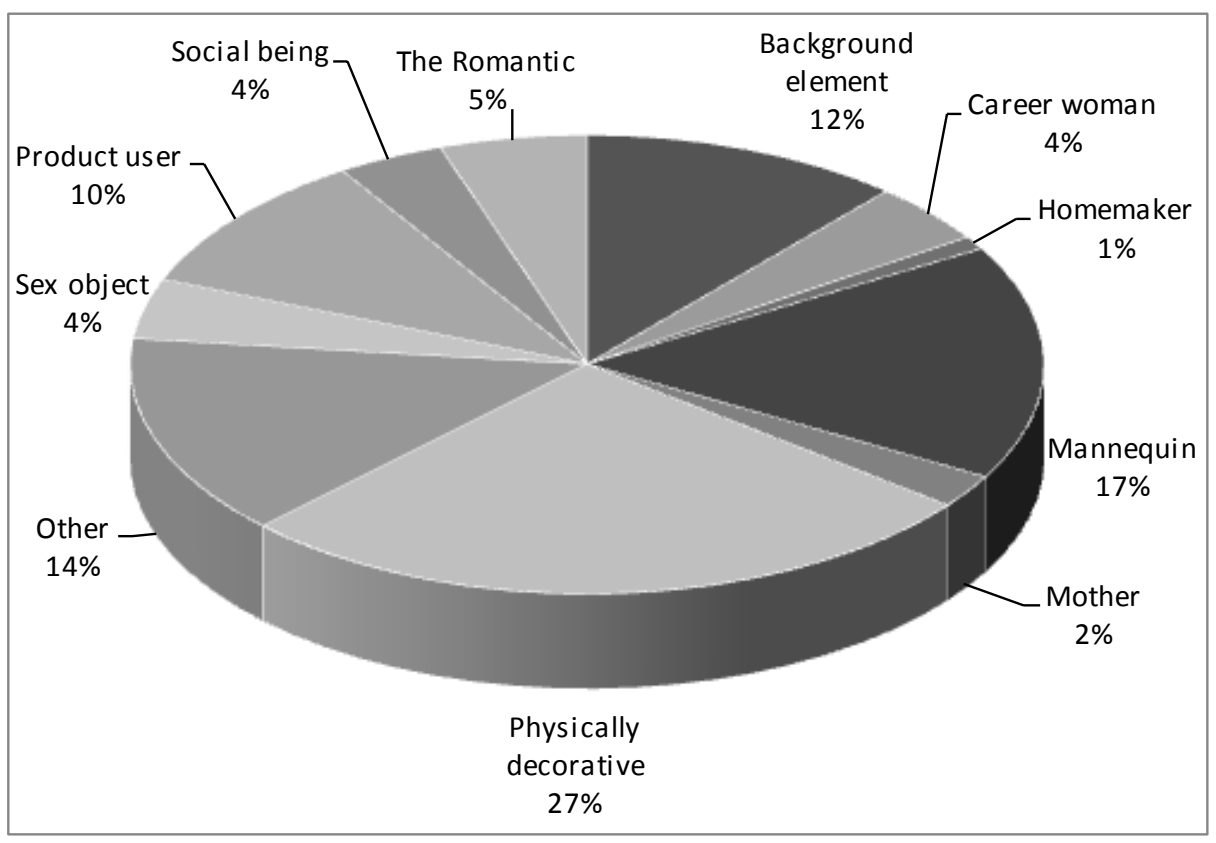

Figure 1 shows that the physically decorative role was most prevalent (27\%), followed by the mannequin (17\%). The third was "other" (14\%); thus a relatively large percentage of the advertisements did not feature a previously recognised portrayal.

Female role portrayals in television advertisements

Figure 2 presents the percentages of the roles found in the television sample.

Figure 2 Role portrayals in television advertisements

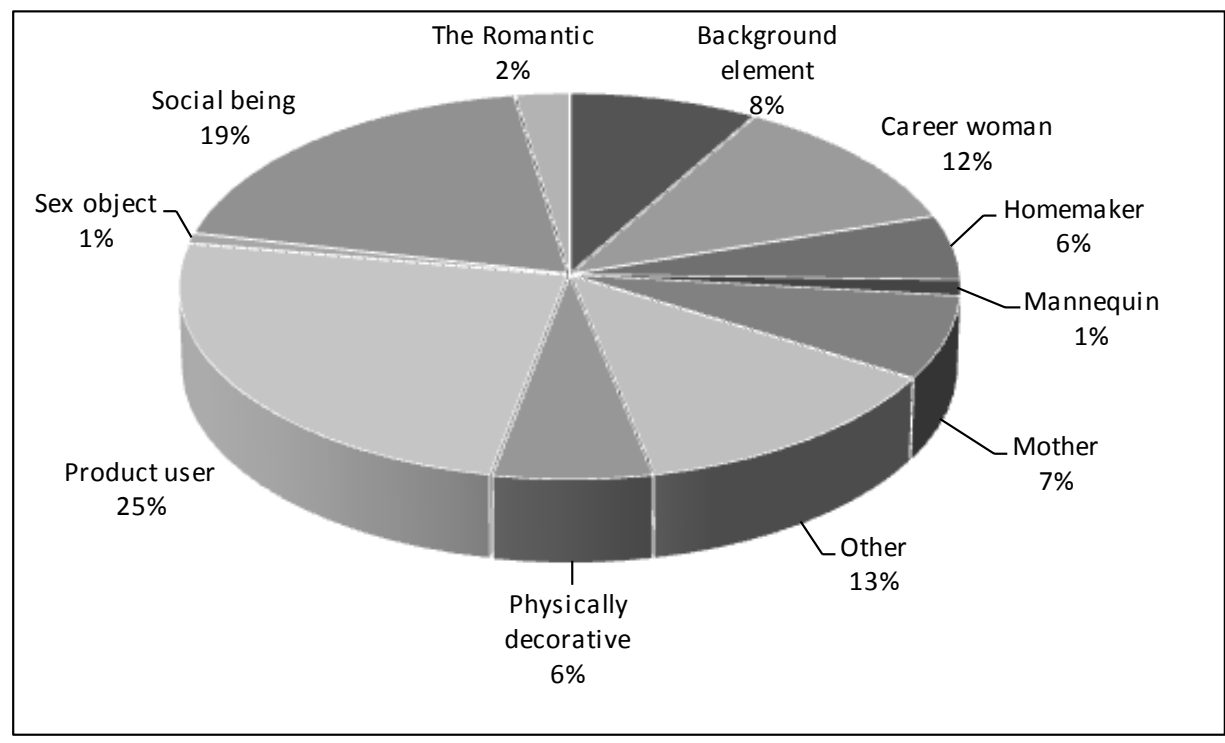


The product user was the most frequently portrayed (25\%), followed by the social being (19\%). Again, "other" was the third most prevalent (13\%).

To determine if new portrayals featured, an in-depth analysis of the "other" categories was conducted using an inductive qualitative process. All "other" portrayals were provided with descriptors, which were examined in order to combine those that were similar (for example "athlete" and "runner"). The portrayals were then evaluated using the same criteria used to define existing categories - character, appearance, props, setting and product - in order to determine if they could be defined as new roles. In addition, the incidence of possible new roles within the "other" category was considered. As no guidelines existed that could be used to determine a cut-off point, the decision was made to consider the top two ("top box") as the most prevalent "other" portrayals.

\section{Analysis of "other" portrayals in magazine advertisements}

Identified descriptors that occurred only once were combined under "various others" as such low incidence was not considered decisive. Table 4 summarises the possible new role categories (from high incidence to low). It also provides brief explanations of the possible new categories and includes the descriptive terms used by coders in coding the "other" portrayals.

Table 4 Possible new role categories in magazine advertisements

\begin{tabular}{|c|c|c|}
\hline $\begin{array}{l}\text { Possible new } \\
\text { categories }\end{array}$ & Brief explanations & Incidence (\%) \\
\hline Leisure woman & $\begin{array}{l}\text { A woman engaging in recreational activities for fun/relaxation purposes } \\
\text { (dancer; holidaymaker; music listener; relax at home; sport fan; } \\
\text { gamer/player of computer games) }\end{array}$ & $23 \%$ \\
\hline Sportswoman & $\begin{array}{l}\text { A woman participating in a specific sport or exercise activity (athlete; } \\
\text { runner; swimmer; yoga/health) }\end{array}$ & $17 \%$ \\
\hline Potential user & $\begin{array}{l}\text { A woman depicted in need (thus potential user) of the advertised product } \\
\text { (for example a woman depicted in pain in an advertisement for pain killers) }\end{array}$ & $13 \%$ \\
\hline Various "other" & Includes fantasy figure, woman modelling for an artist, wild child & $10 \%$ \\
\hline Testimonial provider & $\begin{array}{l}\text { For example, the women depicted as "before" and "after" in weight-loss } \\
\text { advertisements }\end{array}$ & $10 \%$ \\
\hline Customer & $\begin{array}{l}\text { Woman engaging in or depicted with the results of shopping or using } \\
\text { services (client; shopper) }\end{array}$ & $7 \%$ \\
\hline Spoilt woman & Woman treated as superior, high-living (queen; spoilt woman) & $7 \%$ \\
\hline Driver & Woman depicted driving a vehicle & $7 \%$ \\
\hline Inferred user & $\begin{array}{l}\text { Woman showed enjoying the rewards of using the product; no actual use is } \\
\text { depicted thus only inferred (for example, being relieved of discomfort) }\end{array}$ & $7 \%$ \\
\hline
\end{tabular}


The categories that fulfilled the evaluation criteria were leisure woman (23\%) and sportswoman (17\%).

The leisure woman is someone focussing on recreational or relaxation activities. She reflects a relaxed attitude and/or manner and may be depicted indoors or outdoors. The props and product support the recreational actions or enhance the leisure state. Refer to Figure 3 for an example.

Figure 3 Example of the leisure woman portrayal

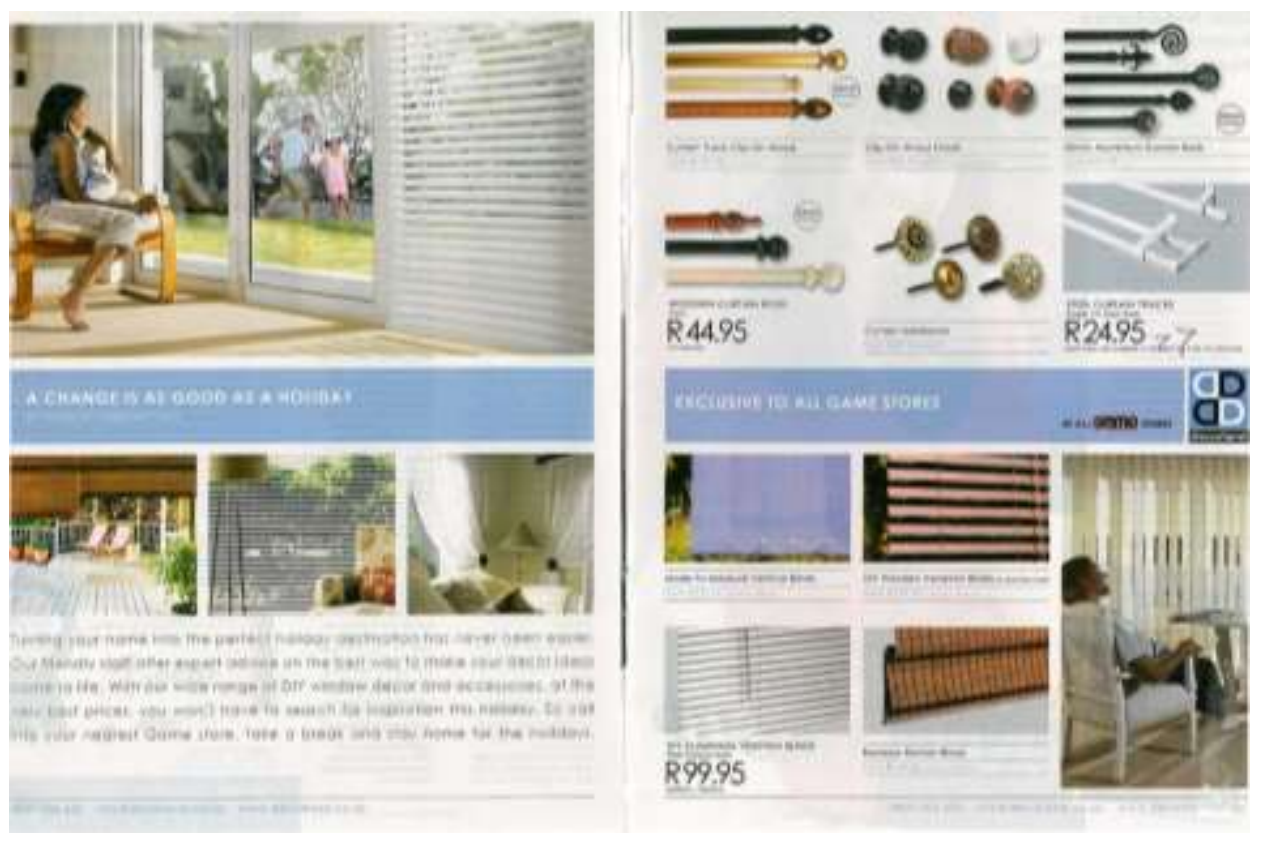

The sportswoman is depicted as exercising or participating in sport. She wears suitable attire, such as exercise clothes. The props are appropriate for the activity - such as a tennis racquet. The setting is conducive to participating in the activity. Figure 4 presents an example. 
Figure 4 Example of the sportswoman portrayal

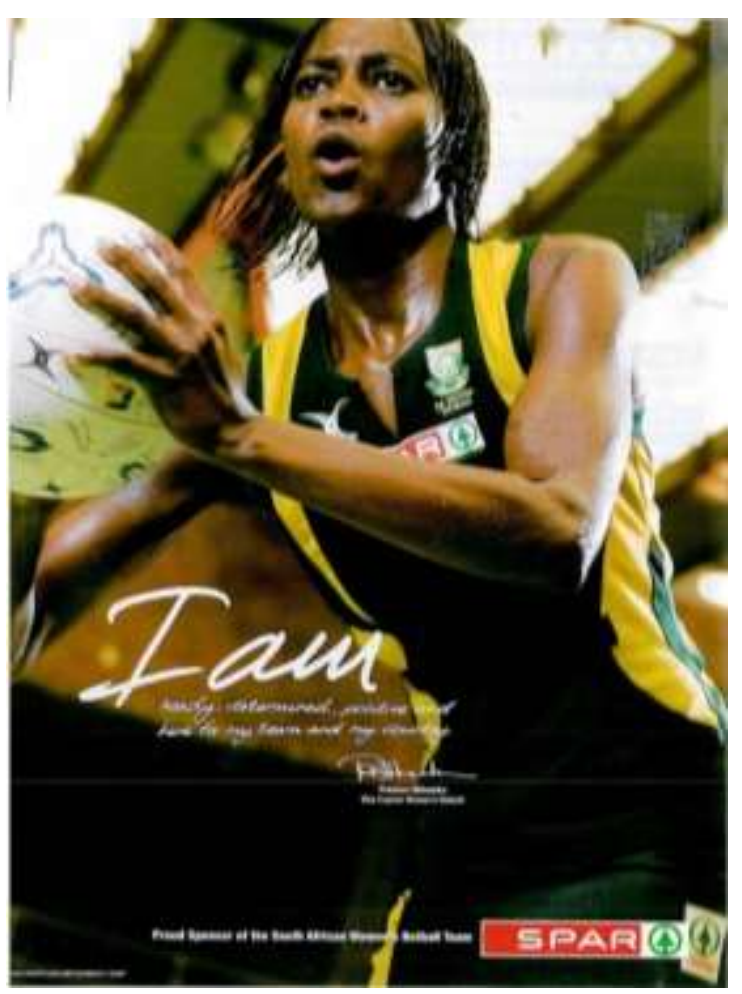

Analysis of "other" portrayals in television advertisements

Table 5 presents the categories, brief explanations and incidence of possible new roles.

Table 5 Possible new role categories in television advertisements

\begin{tabular}{|l|l|l|}
\hline $\begin{array}{l}\text { Possible new } \\
\text { categories }\end{array}$ & Brief explanations & $\begin{array}{l}\text { Incidence } \\
\text { (\%) }\end{array}$ \\
\hline Spokesperson & $\begin{array}{l}\text { Woman providing expert advice and authoritative opinions on the } \\
\text { brand (presenter, interviewer, shares experience, spokesperson) }\end{array}$ & $44 \%$ \\
\hline Customer & $\begin{array}{l}\text { Woman engaging in or depicted with the results of shopping or using } \\
\text { services (client, shopper) }\end{array}$ & $30 \%$ \\
\hline Various "other" & $\begin{array}{l}\text { Includes hygiene conscious person, independent woman, onlooker, } \\
\text { prize winner, spy/thief }\end{array}$ & $10 \%$ \\
\hline Leisure woman & $\begin{array}{l}\text { A woman engaging in recreational activities for fun/relaxation } \\
\text { purposes (traveller, reader, relaxing at home) }\end{array}$ & $6 \%$ \\
\hline Sportswoman & $\begin{array}{l}\text { A woman participating in a specific sport or exercise activity (exerciser, } \\
\text { acrobat) }\end{array}$ & $6 \%$ \\
\hline Inferred user & $\begin{array}{l}\text { Woman showed enjoying the rewards of using the product; no actual } \\
\text { use is depicted thus only inferred (for example, being relieved of } \\
\text { discomfort) }\end{array}$ & $4 \%$ \\
\hline
\end{tabular}

The spokesperson (44\%) and customer (30\%) were identified as new roles. The spokesperson is a representative of a brand or testifies to the benefits thereof. She is authoritative and the setting and props support the demonstration or presentation of the 
brand. She may also portray an interviewer facilitating two-way communication. Refer to Figure 5 for an example.

Figure 5 Example of the spokesperson portrayal

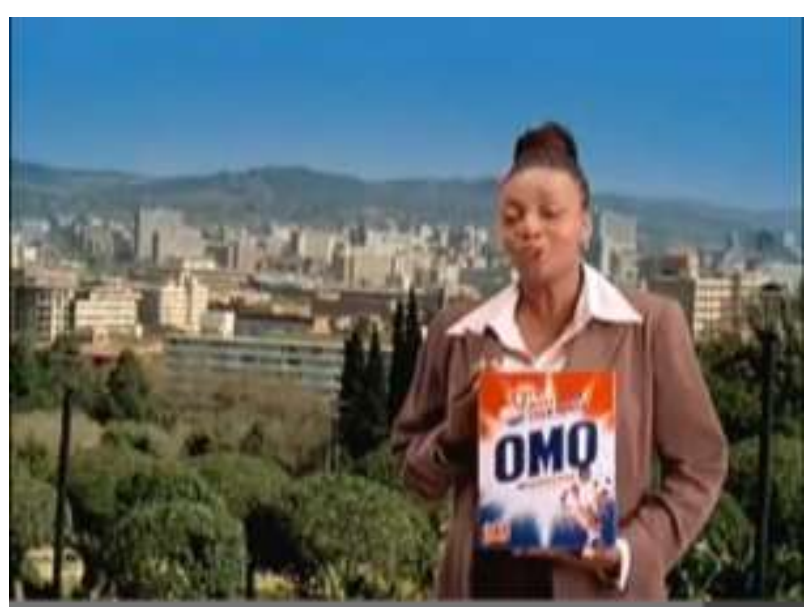

The customer role features a woman selecting or purchasing a product in an informal or formal shopping/retail environment. She could also be depicted after purchasing (carrying bags from a retailer). Figure 6 presents an example.

Figure 6 Example of the customer portrayal

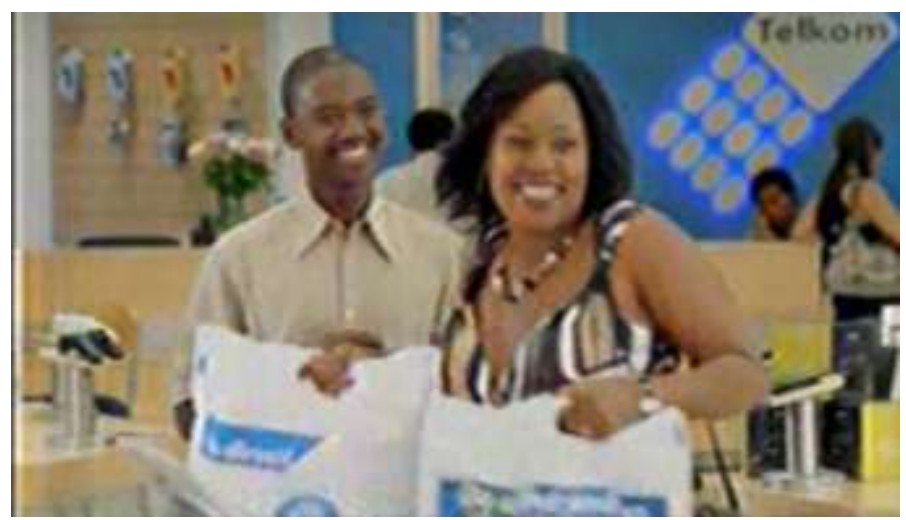

\section{DISCUSSION AND CONCLUSIONS}

Despite the large body of research on female roles in advertisements, no studies reported an analysis of new, atypical roles. This study examined female roles against a background of previously identified categories and delved into the content of the "other" category. 


\section{Portrayals in magazine advertisements}

Women are predominantly portrayed as physically decorative and mannequins, consistent with other research (Bolliger 2008; Döring and Pöschl 2006; Hung and Li 2006; Plakoyiannaki and Zotos 2009; Razzouk et al. 2003). This was even the case in much earlier research by Belkaoui and Belkaoui $(1976,171)$ who compared portrayals over a period of time $(1958$, 1970, 1972), and found that decorative female roles increased in print advertising. This trend occurred despite criticism from the growing women's movement during that era. The mannequin, suitably associated with apparel, was expected in the context of femaleoriented magazines. Rudansky-Kloppers $(1991,169)$, who found the mannequin the most dominant portrayal in 1991, suggested that advertisers lacked creativity as they featured

the mannequin as "go-to" character. The lower incidence of the mannequin in this study may indicate that advertisers have since then limited the mannequin to clothing advertisements.

\section{Portrayals in television advertisements}

In television advertisements women were most often portrayed as product users, consistent with research in Zimbabwe (Furnham et al. 2001, 24), Bulgaria (Ibroscheva 2007, 414) and Australia (Milner and Higgs 2004, 89). The second most portrayed role was the social being, which was also found in previous research (Ibroscheva 2007, 416). Comparing these results with previous research presents challenges as many studies compare gender roles and do not specifically focus on women. Similar assertions on the difficulty of making comparisons were provided by Valls-Fernández and Martínez-Vicente $(2007,696)$.

\section{"Other" portrayals in magazine and television advertising}

In both media the "other" category was the third most featured. This prevalence indicates that South African advertisers feature female portrayals that do not fit into commonly identified categories. While previous studies indicated an "other" category (Das 2011; Ferguson et al. 1990; Milner and Higgs 2004; Sullivan and O'Connor 1988), they did not explore the depictions within it. In this study, the exploration of "other" portrayals identified four new female roles: leisure woman, sportswoman, spokesperson and customer; each representing newly portrayed, atypical dimensions of the modern South African woman. 
The leisure woman refers to women's need for relaxation and recreation. As a sportswoman, women's search for health and an active lifestyle is represented. The woman as a customer represents the woman as a discerning, independent consumer decisionmaker.

The spokesperson epitomises the woman as an authoritative opinion leader. Although elements of the interviewer/narrator in previous research (Das 2011; Furnham and Paltzer 2010) are encompassed in the spokesperson role, it generally referred to the voice-over in the advertisement, which could be authoritative or not. Plakoyiannaki and Zotos (2009, 1417) coded a role category "voice of authority", which was succinctly defined as "the expert" in their United Kingdom study. The expert aspect thereof may be considered comparable to the spokesperson. Authors such as Cagli and Durukan (1989); and Siu and Au (1997) noted the presence of an "on-screen spokesperson", however, it was not coded as a role portrayal. In this study, the spokesperson role was evaluated to be a particular role based on specific, identifiable role criteria (refer to pages 7 and 11) that extended beyond voice-overs. Furthermore, it has not been identified as a specific role in previous research focusing on the South African context.

\section{IMPLICATIONS AND RECOMMENDATIONS}

It is important that advertisers, hoping to engage target audiences and differentiate their brand, use credible visuals that attract attention. Matching the advertising message to the viewpoints of its audience is referred to as congruity (Lee and Schumann 2004, 59). Congruity is often argued to have a positive effect on the audience. From this perspective, it is important to examine the relevance of female portrayals in advertising.

The findings suggest that physically decorative women, remains an important portrayal in magazines, albeit stereotypical. It makes sense from a marketing standpoint as these portrayals are typically used in beauty product advertising and should represent the best possible results of using the brand. That it is so prevalent, however, points to a lack of creativity. The product may be different from the competitors' but the imagery is not. The consumer may find it difficult to differentiate between brands when faced with similar 
images. These brands feature the same portrayals with no attempt at expanding the image to include interesting and varied roles to which the audience can relate.

In the television sample women were most often portrayed as product users or social beings - not typical stereotypes. Depicting a product user aids the connection between the portrayal and the audience: the viewer can picture herself using the brand. This is a good strategy as brand association can be strengthened through the viewer's identification with the image.

Similarly, television is well-suited to social portrayals as people can be depicted enjoying various social interactions, allowing the viewer to connect with the brand. Considering the importance of the social need in the hierarchy of Maslow's motivations (a basic human need and a strong motivator), such portrayals are relevant and should be powerful in facilitating brand association.

The new roles that were identified may be used effectively to differentiate brands. As the leisure role reflects women's need for relaxation, this portrayal is particularly relevant when promoting recreational brands. It could also be used to position mundane products such as home furnishings as something favourably associated with a sense of "deserved" relaxation (refer to Figure 3).

Sportswomen portrayals are appropriate considering the modern trend of healthconsciousness. This is also applicable to non-sports products: active women may identify with this image regardless of what is advertised. It could therefore be a way to differentiate a brand effectively.

Marketers of products that are not generally considered a part of the female domain (such as electronics) should consider featuring the customer role as it portrays a woman who is in control of decision-making. Such portrayals confirm the changing influence of women on household decision-making. Furthermore, portraying customers in a retail environment allows the audience to picture themselves in a purchasing situation. This could enhance brand association as the brand is easy to locate, thus simplifying the buying process. 
Similarly, the spokesperson's expertise helps other consumers' decision-making. This may stimulate word-of-mouth (WOM), which is widely regarded as an important communication influence (Moriarty, Mitchell and Wells 2012, 146).

The new roles place the spotlight on different aspects of the multi-dimensional modern woman. They are not stereotypical and as such provide scope for creativity and avenues for differentiation of brands in media that are notoriously cluttered with promotional messages.

\section{LIMITATIONS}

The study was limited to two media and does not represent all advertising media. The nonprobability sampling does not allow for generalisations beyond the study scope. The samples were limited to popular magazines and free-to-air channels; it is possible that other portrayals may exist in other magazine or channel types. It was limited to the South African context and represented cross-sectional research - thus not allowing longitudinal comparisons.

\section{DIRECTIONS FOR FUTURE RESEARCH}

Researchers should consider not merely allocating non-defined portrayals into the "other" category, but endeavour to examine these for new images. Future research could focus on the new roles to establish if they are more widely featured than is apparent from this study. Incorporating more magazine types and television channels could unearth even more new portrayals. Such research could further contribute to the development of a theoretical framework, which is lacking in current gender role research (Furnham and Paltzer 2010, 223).

The study did not examine the effects of imagery on target audiences; future studies could establish how portrayals are interpreted and internalised. Research that measures the impact of imagery on buying intent could provide valuable insights. Other media could be examined, particularly the growing world of social media that feature many platforms. 


\section{CONCLUDING REMARKS}

Considering the South African focus on female empowerment and the growth of the female market, the results of this study provide interesting insights. South Africa is seen as progressive in terms of gender equality (Van Klaveren, Tijdens, Hughie-Williams and Martin $2009,5)$, thus one would expect depictions in advertising to be consistent with social reality. Moreover, South Africa is a society conscious of women's rights and is sensitive to how women are represented in government and business. As advertising is generally considered reflective of societal norms, according to Eisend in Bush and Furnham (2013), it can serve as a "barometer" of social reality.

The new portrayals revealed in this study reflect a different representation of the modern woman. Her non-stereotypical interests, her power as a consumer and her authority as an opinion leader are depicted. This indicates that advertisers are starting to think outside the stereotype box by featuring different, new portrayals. The modern woman can identify with these as they resonate with her multi-faceted life.

The study contributes to the body of knowledge on female role portrayals in advertising. It provides inputs into the development of a theoretical framework in content analysis. This is achieved by clearly defining common roles as well as examining atypical "other" portrayals to identify new roles. These four distinct new roles may be added to the research agenda. This study paves the way for more focused research in the field.

\section{REFERENCES}

Bartsch, R. A., Burnett, T., Diller, T. R. and Rankin-Williams, E. 2000. Gender representation in television commercials: Updating an update. Sex Roles, 43: 735-743.

Belkaoui, A. and Belkaoui, J. M. 1976. A comparative analysis of the roles portrayed by women in print advertisements: 1958, 1970, 1972. Journal of Marketing Research: 168-172.

Bolliger, D. U. 2008. Perceived gender based stereotypes in educational technology advertisements. TECH TRENDS-WASHINGTON DC-, 52: 46.

Bretl, D. and Cantor, J. 1988. The portrayal of men and women in U.S. television commercials: A recent content analysis and trends over 15 years. Sex Roles, 18: 595609. 
Busby, L. J. and Leichty, G. 1993. Feminism and advertising in traditional and nontraditional women's magazines 1950s-1980s. Journalism \& Mass Communication Quarterly, 70: 247-264.

Bush, B. and Furnham, A. F. 2013. Gender Jenga. Young Consumers: Insight and Ideas for Responsible Marketers, 14: 3-3.

Cagli, U. and Durukan, L. 1989. Sex role portrayals in Turkish TV advertising: some preliminary findings. ODTÜ Gelişme Dergisi, 16: 153-175.

Chow-Hou, W., Mei-Lan, C. and Siok-Kuan, T. 1995. Sex role portrayal in television advertising. International Marketing Review, 12: 49.

Collins, R. L. 2011. Content analysis of gender roles in media: where are we now and where should we go? Sex Roles, 64: 290-298.

Courtney, A. E. and Lockeretz, S. W. 1971. A woman's place: an analysis of the roles portrayed by women in magazine advertisements. Journal of Marketing Research, 8: 92-95.

Das, M. 2011. Gender role portrayals in Indian television ads. Sex Roles, 64: 208-222.

Dominick, J. R. and Rauch, G. E. 1972. The image of women in network TV commercials. Journal of Broadcasting \& Electronic Media, 16: 259-265.

Döring, N. and Pöschl, S. 2006. Images of men and women in mobile phone advertisements: A content analysis of advertisements for mobile communication systems in selected popular magazines. Sex Roles, 55: 173-185.

Dyer, G. 2003. Advertising as communication, Psychology Press.

Eisend, M. 2010. A meta-analysis of gender roles in advertising. Journal of the Academy of Marketing Science, 38: 418-440.

Ferguson, J. H., Kreshel, P. J. and Tinkham, S. F. 1990. In the pages of Ms.: sex role portrayals of women in advertising. Journal of Advertising, 19: 40-51.

Ferrante, C. L., Haynes, A. M. and Kingsley, S. M. 1988. Image of women in television advertising. Journal of Broadcasting \& Electronic Media, 32: 231-237.

Ford, J., Voli, P., Honeycutt, E. and Casey, S. 1998. Gender role portrayals in Japanese advertising: a magazine content analysis. Journal of Advertising, 27: 113-124.

Furnham, A. and Mak, T. 1999. Sex-role stereotyping in television commercials: A review and comparison of fourteen studies done on five continents over 25 years. Sex Roles, 41: 413-437.

Furnham, A., Pallangyo, A. E. and Gunter, B. 2001. Gender-role stereotyping in Zimbabwean television advertisements. South African Journal of Psychology, 31: 21-29.

Furnham, A. and Paltzer, S. 2010. The portrayal of men and women in television advertisements: An updated review of 30 studies published since 2000. Scandinavian Journal of Psychology, 51: 216-236.

Furnham, A. and Spencer-Bowdage, S. 2002. Sex role stereotyping in television advertisements: A content analysis of advertisements from South Africa and Great Britain. Communications, 27: 457-483.

Gilly, M. C. 1988. Sex roles in advertising: a comparison of television advertisements in Australia, Mexico, and the United States. Journal of Marketing, 52: 75-85.

Grau, S. L., Roselli, G. and Taylor, C. R. 2007. Where's Tamika Catchings? A content analysis of female athlete endorsers in magazine advertisements. Journal of Current Issues \& Research in Advertising, 29: 55-65.

Holtzhausen, T., Jordaan, Y. and North, E. J. 2011. The portrayal of women in South African television commercials. Southern African Business Review, 15: 167-183. 
Hung, K. and Li, S. Y. 2006. Images of the contemporary woman in advertising in China: a content analysis. Journal of International Consumer Marketing, 19: 7-28.

Ibroscheva, E. 2007. Caught between East and West? Portrayals of gender in Bulgarian television advertisements. Sex Roles, 57: 409-418.

Ishak, M. 2013. Portrayal of women in Egyptian TV advertising.

Johnson, N. F., Rowan, L. and Lynch, J. 2006. Constructions of gender in computer magazine advertisements: Confronting the literature. SIMILE: Studies In Media \& Information Literacy Education, 6: 1-9.

Koerning, S. K. and Granitz, N. 2006. Progressive Yet Traditional. Journal of Advertising, 35: 81-98.

Kolbe, R. H. and Albanese, P. J. 1996. Man to man: a content analysis of sole-male images in male-audience magazines. Journal of Advertising, 25: 1-20.

Lee, E.-J. and Schumann, D. W. 2004. Explaining the special case of incongruity in advertising: Combining classic theoretical approaches. Marketing Theory, 4: 59-90.

Luyt, R. 2011. Representation of gender in South African television advertising: a content analysis. Sex Roles, 65: 356-370.

Mazzella, C., Durkin, K., Cerini, E. and Buralli, P. 1992. Sex role stereotyping in Australian television advertisements. Sex Roles, 26: 243-259.

Mcarthur, L. Z. and Resko, B. G. 1975. The portrayal of men and women in American television commercials. The Journal of Social Psychology, 97: 209-220.

Milner, L. M. 2005. Sex-role portrayals in African television advertising: A preliminary examination with implications for the use of Hofstede's research. Journal of international consumer marketing, 17: 73-91.

Milner, L. M. and Higgs, B. 2004. Gender sex-role portrayals in international television advertising over time: The Australian experience. Journal of Current Issues \& Research in Advertising, 26: 81-95.

Monk-Turner, E., Kouts, T., Parris, K. and Webb, C. 2007. Gender role stereotyping in advertisements on three radio stations: does musical genre make a difference? Journal of Gender Studies, 16: 173-182.

Moriarty, S., Mitchell, N. D. and Wells, W. D. 2012. Advertising and IMC: Principles and Practice, Prentice Hall.

Mwangi, M. W. 1996. Gender roles portrayed in Kenyan television commercials. Sex roles, 34: 205-214.

Nam, K., Lee, G. and Hwang, J.-S. 2011. Gender stereotypes depicted by Western and Korean advertising models in Korean adolescent girls' magazines. Sex Roles, 64: 223237.

Nassif, A. and Gunter, B. 2008. Gender representation in television advertisements in Britain and Saudi Arabia. Sex Roles, 58: 752-760.

Neuendorf, K. 2011. Content analysis-a methodological primer for gender research. Sex Roles, 64: 276-289.

Paek, H.-J., Nelson, M. and Vilela, A. 2011. Examination of gender-role portrayals in television advertising across seven countries. Sex Roles, 64: 192-207.

Plakoyiannaki, E. and Zotos, Y. 2009. Female role stereotypes in print advertising: Identifying associations with magazine and product categories. European Journal of Marketing, 43: 1411-1434. 
Razzouk, N., Seitz, V. and Vacharante, S. 2003. Content analysis of women's magazine advertising in Thailand: Implications for global branding'. Marketing Management Journal, 13: 118-125.

Rudansky-Kloppers, S. 1991. The roles portrayed by women in magazine advertisements. University of South Africa.

Rudy, R. M., Popova, L. and Linz, D. G. 2010. The context of current content analysis of gender roles: An introduction to a special issue. Sex Roles, 62: 705-720.

Silverstein, A. J. and Silverstein, R. 1974. The portrayal of women in television advertising. Federal Communications Bar Journal, 27: 71-98.

Siu, W.-S. and Au, A. K.-M. 1997. Women in advertising: A comparison of television advertisements in China and Singapore. Marketing Intelligence \& Planning, 15: 235243.

Skelly, G. U. and Lundstrom, W. J. 1981. Male sex roles in magazine advertising, 1959-1979. Journal of Communication, 31: 52-57.

South African Advertising Research Foundation 2009a. Average issue readership of magazines.

South African Audience Research Foundation 2009b. Cume Reach: Satellite universe individuals $16+$.

Sullivan, G. L. and O'connor, P. 1988. Women's role portrayals in magazine advertising: 1958-1983. Sex Roles, 18: 181-188.

Valls-Fernández, F. and Martínez-Vicente, J. M. 2007. Gender stereotypes in Spanish television commercials. Sex Roles, 56: 691-699.

Van Klaveren, M., Tijdens, K., Hughie-Williams, M. and Martin, N. R. 2009. An overview of women's work and employment in South Africa. Amsterdam: AIAS Working Paper: 09-79.

Wee, C.-H., Choong, M.-L. and Tambyah, S.-K. 1995. Sex role portrayal in television advertising: A comparative study of Singapore and Malaysia. International Marketing Review, 12: 49-64.

White, M. D. and Marsh, E. E. 2006. Content analysis: A flexible methodology. Library trends, 55: 22-45.

\footnotetext{
'Owing to space constraints, different studies by the same authors using the same categories were excluded

ii Definitions provided are condensed versions of the detailed code scheme, which can be provided on request
} 